\title{
Critical Limb Ischemia: Laporan kasus
}

\author{
${ }^{1}$ Hermanto Quedarusman, ${ }^{2}$ Pearla Lasut
}

\author{
${ }^{1}$ PPDS Bagian Penyakit Dalam Fakultas Kedokteran Universitas Sam Ratulangi Manado \\ ${ }^{2}$ Bagian Penyakit Dalam Fakultas Kedokteran Universitas Sam Ratulangi Manado \\ Email: hermantoquedarusman@gmail.com
}

\begin{abstract}
We reported a case of 56 years old man with critical limb ischemia. Diagnosis was made based on anamnesis, signs and clinical symptoms, as well as investigations that included the presence of rest pain in the left leg. Patient also had a history of diabetes mellitus. Echodoppler and angiographic investigations supported the diagnosis of critical limb ischemia. In this patient, medicamentous treatment has been administered consisted of antiplatelet and cilostazol, blood sugar control by using insulin. The patient also underwent endovascular revascularization.
\end{abstract}

Keywords: critical limb ischemia, peripheral artery disease

\begin{abstract}
Abstrak: Telah dilaporkan kasus critical limb ischemia pada seorang laki-laki berusia 56 tahun dengan keluhan nyeri seperti terbakar pada kaki kiri bahkan saat istirahat dengan riwayat diabetes melitus. Hasil pemeriksaan penunjang echo-doppler dan angiografi menyokong terdapatnya critical limb ischemia. Diagnosis ditegakkan berdasarkan anamnesis, tanda dan gejala klinis, serta pemeriksaan penunjang. Pada pasien ini, diberikan penatalaksanaan terapi medikamentosa yaitu antiplatelet dan cilostazol, kontrol gula darah dengan menggunakan insulin, dan dilakukan tindakan revaskularisasi endovaskular.
\end{abstract}

Kata kunci: critical limb ischemia, peripheral artery disease

\section{PENDAHULUAN}

Critical limb ischemia (CLI) merupakan kondisi penyakit arteri perifer (PAP) tungkai bawah yang paling berat dimana didapatkan nyeri iskemik saat istirahat, dan ulserasi akibat insufisiensi arteri atau gangren. Lesi iskemik atau gangren dikarenakan adanya obstruksi arteri. Tekanan pergelangan kaki $<50 \mathrm{mmHg}$ biasanya cukup untuk kriteria diagnosis. Berbeda dengan acute limb ischemia (ALI), CLI bersifat kronis yaitu gejala yang terjadi sudah berlangsung selama lebih dari 2 minggu dan merupakan salah satu indikator aterosklerosis berat yang meningkatkan risiko infark miokard, stroke, dan kematian vaskular tiga kali lipat dibandingkan pasien dengan hanya klaudikasio intermitten. ${ }^{1,2}$

Berdasarkan penelitian yang dilakukan oleh TransAtlantic InterSociety Consensus for the Management of Peripheral Arterial Disease (TASC II) didapatkan insidensi kasus CLI berkisar 500-1000 kasus per satu juta penduduk dalam satu tahun di populasi Eropa dan Amerika Utara dengan prevalensi yang lebih tinggi pada laki-laki dibandingkan perempuan (rasio 3:1). Dari penelitian yang sama ditemukan adanya 150.000 kasus per tahun di Amerika Serikat. Suatu penelitian yang dilakukan oleh Medicare dan Medicaid pada tahun 2003 sampai 2008 menemukan bahwa prevalensi terjadinya CLI dalam satu tahun yaitu 2,35\% dan insidensi tahunan kasus CLI mencapai $0,35 \%$ pada kelompok populasi di atas 40 tahun. ${ }^{3-5}$

Critical limb ischemia merupakan kondisi medik yang ditandai dengan adanya nyeri iskemik pada saat istirahat yang terjadi dalam waktu lebih dari dua minggu. 
Pada CLI dapat ditemukan adanya luka atau ulkus yang tidak dapat sembuh bahkan dapat timbul gangren pada salah satu atau kedua tungkai bawah. Diagnosis CLI dibuat berdasarkan adanya gejala dan bukti terjadinya suatu oklusi arteri. Penyakit arteri dapat dibuktikan secara objektif dengan pemeriksaan ankle-brachial index (ABI), toe-brachial index (TBI), transcutaneous pulse oxymetry $\left(\mathrm{TcPO}_{2}\right)$, atau tekanan perfusi kulit. ${ }^{6}$

Pemeriksaan penunjang untuk menilai anatomi pembuluh darah antara lain duplex ultrasound, computed tomographic angiography (CTA), dan magnetic resonance angiography (MRA). Pemeriksaan ini dilakukan untuk mengidentifikasi lokasi dan derajat obstruksi arteri di ekstremitas bawah. $^{7}$

Berikut ini akan dibahas sebuah kasus pasien laki-laki dengan peripheral artery disease dan critical limb ischemia yang menjalani perawatan di RSUP Prof. Dr. R.D. Kandou Manado.

\section{LAPORAN KASUS}

Seorang pasien, Tn. RD berusia 56 tahun, suku Minahasa, sudah menikah, pekerjaan petani, alamat Desa Kadoodan lingkungan I, Bitung Tengah Madidir, Sulawesi Utara, datang ke IGD RSUP Prof. Dr. R. D. Kandou pada tanggal 16 Mei 2018, selanjutnya dirawat di ruang irina C4 dengan keluhan utama nyeri kaki kiri. Pada anamnesis didapatkan keluhan nyeri kaki kiri sejak 3 minggu sebelum masuk rumah sakit, nyeri dirasakan seperti terbakar. Nyeri pada kaki kiri tersebut dirasakan terus menerus dan berkurang dengan pemberian obat penghilang nyeri namun setelah beberapa saat kemudian nyeri tersebut timbul kembali. Nyeri tersebut dapat dirasakan bahkan saat pasien sedang beristirahat dan dapat mereda saat kaki pasien dibiarkan tergantung saat duduk. Nyeri menyebabkan pasien terbangun di malam hari dan menyebabkan penurunan aktivitas seperti berjalan. Pasien mengaku bahwa nyeri pada kaki kirinya semakin lama semakin hebat dan 2 hari sebelum masuk rumah sakit nyerinya sudah tidak tertahankan sehingga pasien mau masuk rumah sakit. Pasien juga mengaku kakinya dingin saat diraba. Pasien telah merasa kesemutan pada kaki kirinya sejak kurang lebih 1 bulan sebelum masuk rumah sakit. Keluhan bengkak pada kaki kiri, demam, dan kelemahan sesisi tubuh disangkal oleh pasien. Demikian pula nyeri dada disangkal oleh pasien. Pasien juga menyatakan tidak pernah mengalami trauma di kaki kiri sebelumnya. Buang air besar dan buang air kecil tidak ada keluhan

Riwayat sakit kencing manis diketahui pasien sejak 2 bulan yang lalu. Pasien meminum Glucovance (gliburid dan metformin) untuk mengontrol gula darahnya namun pasien tidak teratur minum obat dan jarang kontrol ke dokter. Riwayat asam urat tinggi diketahui sejak 7 tahun lalu, pasien mengonsumsi allopurinol namun pasien tidak teratur minum obat dan jarang kontrol ke dokter. Riwayat tekanan darah tinggi, penyakit hati, ginjal, dan jantung sebelumnya disangkal oleh pasien. Mengenai riwayat keluarga, kedua orang tua pasien tidak memiliki riwayat keluhan yang sama atau keganasan lainnya serta tidak memiliki riwayat sakit kencing manis, darah tinggi, hati, penyakit ginjal, dan jantung. Pasien tidak ingat riwayat vaksinasi sebelumnya.

Pemeriksaan fisik didapatkan keadaan umum tampak sakit sedang, kesadaran kompos mentis, tekanan darah 110/70 $\mathrm{mmHg}$, denyut nadi $78 \mathrm{x} / \mathrm{menit}$, teratur, isi cukup, frekuensi pernapasan $20 \mathrm{x} /$ menit, teratur, suhu badan aksiler $36,2^{0} \mathrm{C}$. Tinggi badan $170 \mathrm{~cm}$, berat badan $79 \mathrm{~kg}$, dan indeks massa tubuh (IMT) 27,33 $\mathrm{kg} / \mathrm{m}^{2}$, dengan kesan status gizi berat badan lebih. Dengan menggunakan numeric rating scale (NRS), didapatkan skala nyeri pasien 7. Konjungtiva tidak tampak anemis, sklera tidak ikterik, tidak terdapat perdarahan subkonjungtiva, pupil bulat isokor. Tidak ada lidah kotor dan faring tidak hiperemis. Tidak terdapat pembesaran kelenjar getah bening di leher, ketiak, dan lipat paha, trakea terletak di tengah, tidak ada peningkatan tekanan vena jugularis. Pada pemeriksaan dada, didapatkan pergerakan dinding dada simetris dalam keadaan statis dan 
dinamis, fremitus raba di paru depan dan belakang kanan dan kiri sama, sonor di ke dua lapangan paru, suara pernapasan vesikuler, tidak didapatkan ronki pada kedua lapangan paru, tidak didapatkan adanya bunyi mengi. Pada pemeriksaan jantung, iktus kordis tidak tampak dan tidak teraba, batas jantung kanan pada linea sternalis kanan, batas jantung kiri pada sela iga $\mathrm{V}$ garis midklavikula kiri suara jantung pertama dan kedua normal, teratur, tidak didapatkan bising jantung. Pada pemeriksaan abdomen tampak datar, lemas, peristaltik usus normal, tidak terdapat pembesaran hati dan limpa. Pada ekstremitas didapatkan terjadi perubahan warna menjadi lebih pucat dibandingkan dengan kanan dan pulsasi arteri popliteal kiri lebih lemah dibandingkan dengan yang kanan dan pulsasi arteri dorsalis pedis kiri lebih lemah dibandingkan dengan yang kanan, ekstremitas kiri bawah dingin pada perabaan, nyeri tekan pada ekstermitas kiri bawah, edema pada keempat ekstremitas tidak ada. Pada pasien dilakukan pemeriksaan ABI dan didapatkan pada ABI kiri nilainya 0,63 dan pada ABI kanan nilainya 0,95.

Pemeriksaan laboratorium pada tanggal 16 Mei 2018 didapatkan kadar Hb 13,9 g/dL, hematokrit 42,2\%, lekosit 6.800/ $\mathrm{mm}^{3}$, trombosit $242.000 / \mathrm{mm}^{3}$, eritrosit 4,89 x $10^{6} / \mu \mathrm{L}$, MCH 28,4 pg, MCHC 32,9 g/dl, MCV 86,4 fL, ureum $40 \mathrm{mg} / \mathrm{dL}$, kreatinin $1,2 \mathrm{mg} / \mathrm{dL}$, gula darah sewaktu $384 \mathrm{mg} / \mathrm{dL}$, $\mathrm{Na} 136 \mathrm{mEq} / \mathrm{L}, \mathrm{K}$ 4,53 $\mathrm{mEq} / \mathrm{L}, \quad \mathrm{Cl} 87$ $\mathrm{mEq} / \mathrm{L}$. Hasil pemeriksaan laboratorium urinalisis makroskopik berwana kuning dan jernih sedangkan pada pemeriksaan microskopik didapatkan eritrosit 1-2/LPB, leukosit 1-2/LPB, epitel 2-3/LPK, bakteri, jamur dan amoeba tidak ditemukan. Pada pemeriksaan kimia urin didapatkan berat jenis 1015, pH 5, lekosit (-), nitrit (-), protein (-), glukosa +4 , keton $2+$, urobilinogen (-), bilirubin (-), darah/eritrosit(-), silinder (-), kristal (-). Pemeriksaan EKG ditemukan kesan normal.

Berdasarkan anamnesis, pemeriksaan fisik, serta pemeriksaan laboratorium dan penunjang lainnya, ditegakkan diagnosis kerja sebagai suspek penyakit arteri perifer ekstremitas sinistra inferior, DMT2. Terapi yang diberikan ialah IVFD $\mathrm{NaCl}$ 0,9\% 20 tetes/menit, aspilet $80 \mathrm{mg}$ tiap 24 jam per oral pemberian sore hari, clopidogrel $75 \mathrm{mg}$ tiap 24 jam per oral pemberian sore hari, cilostazol tiap 12 jam per oral, parasetamol $500 \mathrm{mg}$ tiap 8 jam per oral, novorapid 4 unit tiap 8 jam injeksi subkutan, levemir 12 unit tiap 24 jam injeksi subkutan malam hari. Pasien direncanakan untuk dilakukan pemeriksaan gula darah 4 porsi setiap hari, echo-Doppler, dan dikonsulkan ke Bagian Mata, Neurologi, dan Gizi.

Hari kedua perawatan, keluhan nyeri kaki kiri berkurang dibandingkan saat masuk rumah sakit, keadaan umum sakit sedang, kesadaran kompos mentis. Tekanan darah 120/80 mmHg, denyut nadi $82 \mathrm{x} /$ menit, frekuensi pernapasan $20 \mathrm{x} /$ menit, suhu badan aksiler $36,7^{\circ} \mathrm{C}$. Dengan menggunakan NRS, didapatkan skala nyeri pasien 6. Hasil pemeriksaan gula darah 4 porsi yaitu $283 \mathrm{mg} / \mathrm{dL}$ pada jam 6 sore, 252 mg/dL pada jam 10 malam dan 220 mg/dL. Hasil pemeriksaan echo-Doppler arteri femoralis proksimal-distal sinistra flow $(+)$, trifasik $(+)$, arteri tibialis posterior sinistra flow $(+)$, monofasik $(+)$, vena femoralis et popliteal sinistra thrombus (-), vena femoralis dan vena tibialis posterior refluks $(+)$, kesan dari pemeriksaan tersebut yaitu CLI ekstremitas kiri bawah, dan berda-sarkan klasifikasi Fontaine dan Rutherford, pasien ini masuk dalam klasifikasi Fontaine III dan Rutherford 4 karena sudah terjadi nyeri iskemik bahkan saat istirahat. Hasil pemeriksaan Bagian Neurologi mendapatkan inspeksi kaki kiri pasien lebih pucat dan yang kanan dan kesan kulit kering, pada perabaan didapatkan poikilotermia. Pada pemeriksaan muskuloskeletal didapatkan adanya claw toes. Dari hasil pemeriksaan neurologi yaitu pemeriksaan sensorik kaki dengan menggunakan cotton wool untuk sensasi raba dan pin untuk sensasi nyeri dan juga pemeriksaan persepsi vibrasi dengan menggunakan garpu tala $128 \mathrm{~Hz}$ didapatkan adanya penurunan sensasi raba, nyeri dan vibrasi pada kaki kiri dan kanan. Pasien didiagnosis kerja sebagai critical limb ischemia ekstremitas kiri bawah 
Fontaine III dan Rutherford 4, DMT2, dan polineuropati DM. Dosis insulin ditingkatkan yaitu novorapid 6 unit tiap 8 jam dan levemir 14 unit, pasien juga diberikan gabapentin $150 \mathrm{mg}$ tiap 12 jam dan vitamin B1B6B12 1 tablet (vit B1 $100 \mathrm{mg}$, vit B6 $200 \mathrm{mg}$, dan vit B12 $200 \mathrm{mcg}$ ) tiap 8 jam dan terapi lain dilanjutkan. Pasien direncanakan untuk dikonsulkan ke Bagian Bedah Vaskular.

Hari ketiga perawatan, keluhan nyeri pada kaki kiri, keadaan umum sakit sedang, kesadaran kompos mentis. Tekanan darah 110/70 mmHg, denyut nadi $80 \mathrm{x} /$ menit, frekuensi pernapasan $20 \mathrm{x} / \mathrm{menit}$, suhu badan aksiler $36,5^{0} \mathrm{C}$. Dengan menggunakan NRS, didapatkan skala nyeri pasien 6 . Pasien dikonsulkan ke Bagian Bedah Vaskular dan disarankan untuk dilakukan pemeriksaan SGOT, SGPT, PT, INR, dan APTT. Pasien direncanakan akan dilakukan angiography dan angioplasty oleh bedah vaskular. Diagnosis kerja critical limb ischemia ekstremitas kiri bawah Fontaine III dan Rutherford 4, DMT2 dan polineuropati DM. Terapi masih dilanjutkan.

Hari kelima perawatan, keluhan nyeri pada kaki kiri, keadaan umum sakit sedang, kesadaran kompos mentis. Tekanan darah 120/70 mmHg, denyut nadi 83 x/menit, frekuensi pernapasan $20 \mathrm{x} / \mathrm{menit}$, suhu badan aksiler $36,5^{0} \mathrm{C}$. Dengan menggunakan NRS, didapatkan skala nyeri pasien 6 . Hasil pemeriksaan laboratorium SGOT 10 U/L, SGPT 8 U/L, PT 12,6 detik, INR 1,00 detik, dan APTT 27,2 detik. Diagnosis kerja sebagai critical limb ischemia ekstremitas kiri bawah Fontaine III dan Rutherford 4, DMT2, dan polineuropati diabetik. Terapi dilanjutkan dan pada pasien dijadwalkan untuk angiography dan angioplasty keesokan harinya.

Hari keenam perawatan, keluhan nyeri pada kaki kiri, keadaan umum sakit sedang, kesadaran kompos mentis. Tekanan darah 120/80 mmHg, denyut nadi $84 \mathrm{x} /$ menit, frekuensi pernapasan $20 \mathrm{x} /$ menit, suhu badan aksiler $36,3^{0} \mathrm{C}$. Dengan menggunakan NRS, didapatkan skala nyeri pasien 6 . Pasien dilakukan angiography dan ditemukan adanya stenosis arteri popliteal distal, pasien kemudian dilakukan angioplasty. Diagnosis kerja sebagai critical $\operatorname{limb}$ ischemia ekstremitas kiri bawah Fontaine III dan Rutherford 4, DMT2, dan polineuropati DM. Terapi lain pada pasien dilanjutkan

Hari ketujuh perawatan, keluhan nyeri kaki kiri berkurang, keadaan umum sakit sedang, kesadaran kompos. Tekanan darah 110/80 mmHg, denyut nadi $82 \mathrm{x} / \mathrm{menit}$, frekuensi pernapasan $20 \mathrm{x} /$ menit, suhu badan aksiler $36,7^{0} \mathrm{C}$. Dengan menggunakan NRS, didapatkan skala nyeri pasien 4. Pasien direncanakan untuk dilakukan rawat jalan dan diberikan terapi rawat jalan aspilet $80 \mathrm{mg}$ tiap 24 jam per oral pemberian sore hari, clopidogrel $75 \mathrm{mg}$ tiap 24 jam per oral pemberian sore hari, cilostazol tiap 12 jam per oral, parasetamol $500 \mathrm{mg}$ tiap 8 jam per oral, gabapentin 150 mg tiap 12 jam, vitamin B1B6B12 1 tablet (vit B1 100 mg, vit B6 200 mg, dan vit B12 $200 \mathrm{mcg}$ ) tiap 8 jam, novorapid 8 unit tiap 8 jam injeksi subkutan, levemir 14 unit tiap 24 jam injeksi subkutan malam hari. Pasien diberi anjuran untuk kontrol di Poliklinik Bedah Vaskular, Poliklinik Endokrin, dan Poliklinik Neurologi.

\section{BAHASAN}

Critical limb ischemia adalah kondisi medis yang ditandai dengan adanya nyeri iskemik pada saat istirahat yang terjadi dalam waktu lebih dari dua minggu. Pada CLI dapat ditemukan adanya luka atau ulkus yang tidak dapat sembuh bahkan dapat timbul gangren pada salah satu atau kedua tungkai bawah. Berdasarkan penelitian yang dilakukan oleh TransAtlantic InterSociety Consensus for the Management of Peripheral Arterial Disease (TASC II) didapatkan bahwa prevalensi kasus CLI lebih tinggi pada laki-laki dibandingkan dengan perempuan dengan rasio 3:1.-6 Pasien merupakan laki-laki yang mengalami nyeri kaki pada saat istirahat dalam jangka waktu selama 3 minggu.

Faktor risiko terjadinya CLI dapat berupa usia pada saat penilaian awal, jenis kelamin laki-laki, DM, hipertensi dan riwayat infark miokard, stroke, gagal jantung, 
atau gagal ginjal. Diabetes merupakan salah satu faktor yang berperan dalam meningkatkan insidensi dan prevalensi CLI, dan pasien dengan DM seringkali menunjukkan gejala dan tanda penyakit arteri yang lebih berat dan risiko lebih besar terjadinya infeksi dan frekuensi dilakukannya amputasi. Hasil beberapa penelitian menunjukkan bahwa pasien dengan DM berisiko empat kali lebih besar untuk mengalami CLI dibandingkan pasien tanpa DM. Hal itu dikarenakan pasien dengan DM sering kali mengalami neuropati perifer dengan disfungsi sensorik yang diperkirakan berkontribusi dalam terjadinya ulkus pada ekstremitas bawah dan kehilangan jaringan yang progresif pada pasien CLI. Penelitian yang sama juga menunjukkan bahwa pasien CLI dengan DM berisiko lebih tinggi untuk diamputasi dalam lima tahun perjalanan penyakit dibandingkan pasien tanpa DM. ${ }^{8-10}$ Pasien juga merupakan laki-laki yang telah menderita DM yang baru diketahuinya sejak dua bulan lalu.

Critical limb ischemia biasanya disebabkan karena adanya penyakit aterosklerotik obstruktif, namun CLI dapat pula disebabkan oleh adanya penyakit ateroembolik atau tromboembolik, vaskulitis, trombosis in situ yang berhubungan dengan keadaan hiperkoagulasi, tromboangiitis obliterans, penyakit adventisia kistik, terjebaknya arteri popliteal, atau trauma. Tanpa memandang etiologinya, patofisiologi CLI merupakan proses kompleks dan kronik yang melibatkan sistem makrovaskular dan mikrovaskular, beserta jaringan sekitar yang terlibat. Respon tubuh terhadap iskemia berupa terjadinya angiogenesis dan arteriogenesis untuk membentuk pembuluh darah kolateral yang berperan memperlancar aliran darah ke ekstremitas yang terkena. Jika respon tersebut gagal memberikan pasokan yang dibutuhkan ke ekstremitas, maka pasien berisiko untuk mengalami iskemia ekstremitas. Pembuluh darah pada pasien dengan CLI seringkali mengalami penurunan ketebalan dinding dan rasio lumen ke dinding menurun. Hal ini dapat menimbulkan edema ekstremitas yang dapat menyebabkan kompresi pembuluh darah sekitar sehingga memperburuk aliran darah ke ekstremitas yang terlibat.

Klasifikasi penyakit arteri perifer terdiri atas Fontaine dan Rutherford. Klasifikasi Fontaine dibagi menjadi lima yaitu: (I) asimtomatik; (IIa) klaudikasio ringan; (IIb) klaudikasio sedang hingga berat; (III) nyeri saat istirahat; dan (IV) terjadi ulkus atau gangren. Klasifikasi Rutherford terdiri atas tujuh, yaitu: (0) asimtomatik; (1) klaudikasio ringan; (2) klaudikasio sedang; (3) klaudikasio berat; (4) nyeri saat istirahat; (5) kehilangan jaringan minor; dan (6) kehilangan jaringan berat atau gangren. ${ }^{11-12}$ Pada pasien ini terjadi nyeri saat istirahat, tetapi belum tampak adanya kerusakan jaringan berupa ulkus atau gangren, sehingga masuk dalam klasifikasi Fontaine III dan Rutherford 4.

Pemeriksaan fisik yang dapat dilakukan pada pasien yang dicurigai dengan CLI yaitu pemeriksaan sederhana pada kaki yang dicurigai yaitu palpasi pulsasi arteri ekstremitas, adanya perubahan warna dari ekstremitas bawah, kurangnya rambut pada ekstremitas yang terkena, dan meningkatnya capillary refill time (CRT) ekstremitas yang terkena. Luka maupun gangren juga dapat terjadi pada ekstremitas yang terkena. Tingkat keparahan dari iskemia kaki tersebut dapat dikonfirmasi dengan menggunakan beberapa uji vaskular non invasif seperti, ankle-brachial index (ABI), toebrachial index (TBI), maupun transcutaneous oxygen pressure (TcPO). Pada pemeriksaan ABI jika didapatkan hasil kurang dari 0,9 maka pasien dicurigai mengalami PAP, namun pada ABI kurang dari 0,4 maka pasien dicurigai mengalami CLI. Keuntungan dari permeriksaan ABI yaitu dapat membantu menegakkan diagnosis dan perfusi jaringan ekstremitas, dapat juga digunakan untuk memonitor manfaat dari revaskularisasi, dan selain itu pemeriksaan ABI murah dan mudah dilakukan. Kerugian dari pemeriksaan ABI yaitu dapat meningkat pada pembuluh darah yang mengeras dan tidak dapat dikompresi seperti pada pasien usia lanjut serta penyandang DM dan penyakit ginjal, tidak 
dapat melokalisasi letak pembuluh darah yang terkena, dapat normal atau mendekati normal pada arteri infrapoplitea yang terisolasi. ${ }^{13}$ Pada pasien ini dilakukan pemeriksaan fisik kaki yang terkena dan didapatkan pulsasi arteri popliteal kiri lebih lemah dibandingkan dengan yang kanan dan pulsasi arteri dorsalis pedis kiri lebih lemah dibandingkan dengan yang kanan; ekstremitas kiri bawah dingin pada perabaan dan terjadi perubahan warna menjadi lebih pucat dibandingkan dengan kanan; serta nyeri tekan pada ekstermitas kiri bawah. Pada pasien dilakukan pemeriksaan ABI dan didapatkan nilai ABI kiri 0,63 dan ABI kanan 0,95.

Pemeriksaan anatomi pembuluh darah dapat menggunakan pemeriksaan pencitraan seperti duplex ultrasound, computed tomographic angiography (CTA), magnetic resonance angiography (MRA), dan angiografi invasif. Pemeriksaan ini digunakan dalam praktik klinis untuk mengidentifikasi PAP dan untuk mengidentifikasi lokasi dan derajat obstruksi arteri di ekstremitas bawah. Di kebanyakan pusat kesehatan, Doppler ultrasound yang selalu tersedia, namun tes ini memiliki kekurangan pada pasien dengan obesitas dan sulit untuk menilai patensi arteri tibialis dan pedis karena adanya calcific shadowing. Pemeriksaan CTA dapat dilakukan pada pasien dengan PAP dan dapat memberikan informasi yang penting mengenai penyakit aortoiliaka dan femoropopliteal, tetapi manfaatnya berkurang pada pasien dengan arteri tibialis dan pedis yang mengalami kalsikasi berat. Selain itu, CTA juga membutuhkan kontras teriodinisasi sehingga penggunaannya dibatasi pada pasien dengan kelainan ginjal. Pemeriksaan MRA tidak menimbulkan radiasi namun secara teknis membutuhkan waktu lebih lama dan dapat juga dipengaruhi calcific shadowing. ${ }^{7}$ Pada pasien ini dilakukan pemeriksaan Doppler ultrasonography. Hasil pemeriksaan echo-doppler ialah arteri femoralis proksimal-distal sinistra aliran darah masih ada, arteri tibialis posterior sinistra aliran darah masih ada, vena femoralis et popliteal sinistra aliran baliknya tidak ada, vena femolaris dan vena tibialis posterior aliran balik masih ada, dengan kesan dari pemeriksaan tersebut yaitu CLI ekstremitas kiri bawah.

Pemeriksaan angiografi invasif sering digunakan untuk menglarifikasi potensi untuk dilakukan revaskularisasi dan dapat dilakukan sebelum dilakukan amputasi. Angiografi juga menggunakan kontras teriodinasi dan memberikan resolusi ruang terbesar dibandingkan pemeriksaan non invasif. Angiografi invasif merupakan baku emas untuk mendiagnosis CLI, namun angiografi merupakan modalitas pencitraan yang mahal dan membutuhkan penggunaan kontras teriodinasi yang bersifat nefrotosik. Sifat invasif pemeriksaan ini juga berpotensi menyebabkan timbulnya komplikasi lokal maupun sistemik seperti hematoma, pseudoaneurisma, fistula arteriovenosa, dan embolisasi. Oleh karena itu pada pemeriksaan ini diperlukan tindakan yang cermat untuk mencari akses arteri yang tepat untuk meminimalisasi risiko. ${ }^{14-15}$ Pada pasien ini dilakukan angiografi invasif dan hasil pemeriksaan tersebut mengonfirmasi adanya CLI dengan menemukan adanya stenosis arteri popliteal sinistra.

Pasien dengan CLI memiliki risiko besar untuk dilakukan amputasi dan dapat menyebabkan kejadian iskemik kardiovaskular. Penatalaksanaan CLI termasuk evaluasi untuk revaskularisasi dan terapi penyembuhan luka dengan tujuan untuk meminimalisasi kehilangan jaringan dan untuk penyembuhan luka dan memelihara fungsi ekstremitas. Terapi medikamentosa juga berperan untuk menghindari terjadinya kejadian iskemik kardiovaskular dan merupakan elemen penting dalam penatalaksanaan CLI. Revaskularisasi pada CLI dapat dilakukan melalui pembedahan atau secara endovaskular untuk membantu mengembalikan aliran darah pada kaki melalui setidaknya satu arteri paten. Tindakan ini membantu mengurangi nyeri iskemik dan membantu penyembuhan luka. Suatu penelitian yang dinamakan BASIL (Bypass versus angioplasty in severe ischemia of the leg) menunjukkan bahwa tidak ada perbedaan bermakna antara 
revaskularisasi endovaskular atau angioplasty dan pembedahan dalam mengurangi angka amputasi dalam dua tahun, namun revaskularisasi endovaskular lebih diprioritaskan karena komplikasi yang lebih rendah. Pada pasien dengan DM, kontrol gula darah sangat penting untuk mengurangi angka amputasi dan meningkatkan patensi pembuluh darah setelah revaskularisasi. Terapi medikamentosa yang dapat diberikan antara lain antiplatelet seperti golongan salisilat (aspirin) dan adenosine diphosphat receptor inhibitor dianjurkan untuk menghindari kematian jaringan akibat iskemik (rekomendasi A). Pemberian dua jenis antiplatelet (dual antiplatelet) berperan dalam mengurangi risiko komplikasi setelah revaskularisasi (rekomendasi C). Cilostazol merupakan terapi medikamentosa yang efektif dalam menangani gejala dan mengurangi klaudikasio saat berjalan sehingga meningkatkan jarak tempuh (rekomendasi A). Selain itu, perubahan gaya hidup seperti berhenti merokok dianjurkan pada pasien dengan CLI (rekomendasi A). ${ }^{6,16}$ Pada pasien ini diberikan terapi medikamentosa yaitu aspilet $80 \mathrm{mg}$ tiap 24 jam per oral pemberian sore hari, clopidogrel $75 \mathrm{mg}$ tiap 24 jam per oral pemberian sore hari, cilostazol tiap 12 jam per oral. Untuk kontrol gula darah diberikan novorapid 4 unit tiap 8 jam injeksi subkutan, levemir 12 unit tiap 24 jam injeksi subkutan malam hari. Terapi invasif yang dilakukan untuk revaskularisasi yaitu revaskularisasi endovaskular atau angioplasty. Terapi antiplatelet dilanjutkan setelah revaskularisasi.

Critical limb ischemia merupakan bentuk penyakit arteri perifer yang sangat buruk dan memiliki prognosis yang kurang baik. Data menunjukkan bahwa 30\% pasien dengan CLI dilakukan amputasi setelah satu tahun sejak diagnosis ditegakkan, dan 25\% pasien meninggal akibat komplikasi kasus ini. Pada studi yang dilakukan TASC A/B dan TASC C/D pada pasien CLI yang sudah dilakukan angioplasty, persentase tingkat selamatnya anggota tubuh pasien dalam 3 tahun yaitu $42 \%$ dan $40 \%$. Faktor komorbiditas yang dapat berperan antara lain DM, hipertensi, dan disfungsi renal. 17,18 Prognosis pada pasien ini yaitu ad vitam dubia ad bonam, ad fungsionam dubia ad malam dan ad sanationam dubia ad malam.

\section{SIMPULAN}

Telah dilaporkan sebuah kasus critical limb ischemia pada seorang laki-laki berusia 56 tahun dengan DMT2. Diagnosis ditegakkan berdasarkan anamnesis, tanda dan gejala klinis, serta pemeriksaan penunjang echo-doppler dan angiografi. Penatalaksanaan yang diberikan ialah terapi medikamentosa dengan antiplatelet dan cilostazol, kontrol gula darah dengan insulin, dan tindakan revaskularisasi endovaskular.

\section{DAFTAR PUSTAKA}

1. Antono D, Hamonangani. Penyakit arteri perifer. In: Setiati S, Alwi I, Sudoyo AW, Simadibrata M, Setiyohadi B, Syam AF, editors. Buku Ajar Ilmu Penyakit Dalam Jilid II (6th ed). Jakarta: Interna publishing, 2014; p. 1516-26.

2. Teraa M, Conte MS, Moll FL, Verhaar MC. Critical limb ischemia: current trends and future directions. J Am Heart Assoc. 2016;5:1-8.

3. Gulati A, Garcia L, Acharji S. Epidemiology of chronic critical limb ischemia. Critical limb ischemia. Boston: Springer International Publishing Switzerland, 2017; p. 9-14.

4. Fowkes GR, Aboyans V, Fowkes FJI, McDermott MM, Sampson UKA, Criqui MG. Peripheral artery disease: epidemiology and global perspectives. Nat Rev Cardiol. 2017;14(3):156-70.

5. Norgren L, Hiatt WE, Dormandy JA, Nehler MR, Harris KA, Fowkes FGR. InterSociety Consensus for the management of peripheral arterial disease (TASC II). Eur J Vasc Endovasc Surg. 2007;33:170.

6. Gerhard-Herman MD, Gornik HL, Barrett C, Barshes NR, Corriere MA, Dracman DE, et al. 2016 AHA/ACC Guideline on the management of patients with lower extremity peripheral artery disease: Executive summary: A report of the American College of Cardiology/American Heart Associ- 
ation Task Force on Clinical Practice Guidelines. Circulation. 2017;135(12): e686-e725.

7. Shishehbor MH, White CJ, Gray BH, Menard MT, Lookstein R, Rosen-field K, et al. Critical limb ischemia: an expert statement. J Am Coll Cardiol. 2016; 68(18):2003-15.

8. Nehler MR, Duval S, Annex BH, Hiatt WR, Rogers K, Zakharvan A, et al. Epidemiology of peripheral arterial disease and critical limb ischemia in an insured national population. J Vasc Surg. 2014;60(3):686-95.

9. Carthy ER. Lower limb peripheral arterial disease (Clinical Guideline 147): A guideline summary. Ann Med Surg. 2013;2(1):26-30.

10. Spreen MI, Gremmels H, Teraa M, Sprengers RW, Verhaar MC, van Eps SRG, et al. Diabetes mellitus is associated with decreased limb survival in patients with critical limb ischemia: pooled data from two randomized controlled trials. Diabetes Care, 2016; 39(11):2058-64.

11. Varu VN, Hogg ME, dan Kibbe MR. Critical limb ischemia. J Vasc Surg. 2015; 51(1):230-41.

12. Awtry EH. Vascular disease. In: Longo DL, Kasper DL, Jameson JL, Fauci AS, Hauser SL, Loscalzo JM, editors. Disorders of Cardiovascular Disease. Harrison's Principle of Internal Medicine. California: Mc Graw Hill, 2012; p. 503-60.

13. Farber A, Eberhardt RT. The current state of critical limb ischemia: A systematic review. JAMA surgery. 2016;17:1-8.

14. Kinlay S. Management of critical limb ischemia. Circ Cardiovasc Interv. 2016;9(2):e001946.

15. Fabiani I, Calogero E, Pugliese NR, Di Stefano R, Nicastro I, Buttitta F. Clinical limb ischemia: A practical upto-date review. Angiology. 2017:1-10. DOI: $10.1177 / 0003319717739387$.

16. Aboyans V, Ricco JB, Bartelink MEL, Bjorck M, Brodmann M, Cohnert T, et al. Editor's Choice e 2017 ESC Guidelines on the Diagnosis and Treat-ment of Peripheral Arterial Diseases, in collaboration with the European Society for Vascular Surgery (ESVS) Document covering atherosclerotic disease of extracranial carotid and vertebral, mesenteric, renal, upper and lower extremity arteries. Eur Heart J. 2018;39(9):763-816.

17. Hammad TA, Prasad A. The contemporary role of stents and angioplasty for the treatment of infrapopliteal disease in critical limb ischemia. Curr Cardiol Rep. 2017;19(7):58.

18. Singh GD, Brinza EK, Hildebrand J, Waldo SW, Foley TR, Laird JR, et al. Midterm outcomes after infra-popliteal interventions in patients with critical limb ischemia based on the TASC II Classification of below-the-knee arteries. J Endovasc Ther. 2017;24(3): 321-30. 